\title{
Electricity Power, Democratic Governance and Economic Growth: Evidence from Nigeria
}

\author{
Ibrahim Kabiru Maji $^{*}$, Salisu Ibrahim Waziri ${ }^{\text {b }}$ \\ a Department of Economics, Nigerian Army University Biu \\ ${ }^{\mathrm{b}}$ Department of Economics, Bauchi State University \\ * Corresponding author's email: keibimaji@gmail.com
}

\begin{abstract}
The study examines the impact of democratic governance and corruption on electricity power supply in Nigeria. To achieve this goal, an integrated regression analysis such as Dynamic Ordinary Least Squares (DOLS), Fully Modified OLS, Canonical Cointegrating Regression and OLS were utilized to estimate data spanning the period of 1986 - 2020. The result revealed a negative and significant impact of democracy and corruption on electricity power generation in Nigeria. On the other hand, economic growth has shown a positive and important impact on electricity generation, suggesting that higher GDP growth will increase the supply of electricity in Nigeria. The implication of this findings are as follows: (i) one of the dividends of democracy which is providing public good to the citizens have not been achieved, as such, policymakers need to give more attention to the provision electricity supply; (ii) the institutions in charge of fighting corruption such as the Economic and Financial Crime Commissions (EFCC) need to be further strengthened in Nigeria.
\end{abstract}

Keywords: electricity; democracy; corruption; economic growth; Nigeria

\section{How to Cite:}

Maji, I. K., \& Waziri, S. I. (2021). Electricity power, democratic governance and economic growth: evidence from Nigeria. International Journal of Business, Management \& Econominc, 2(3). 198-207. DOI: https://doi.org/10.47747/ijbme.v2i3.338

\section{Introduction}

Electricity power is an essential energy that is used for domestic and economic activities in most countries of the world. Electricity is used for household and street lights; generating power in the industries and for enhancing social facilities like education, healthcare and modern communication (Ahlborg et al., 2015). As such, providing clean and affordable electricity to a country's citizens will contribute in reducing inequality and as well assist the country to achieve goal seven of the Sustainable Development Goals (SDGs) which aims to achieve clean, reliable and affordable energy for all (SDGs report, 2017).

In order to efficiently provide a public good such as electricity, it was argued that the democratic system of governance in which the rulers of a country are held accountable to the citizens is 
more superior to other forms of governance (Acemoglu and Robinson, 2006). Through the election process, the citizens can replace a ruler that did not meet up with their expectation of providing public goods like electricity, education and health care. As such, it can be hypothesized that good democratic governance can lead to affordable electricity and thus economic growth.

Despite that, the provision of electricity is central to Nigeria's National Energy Master Plan (NEMP), the provision of clean and affordable electric power to household, private sectors and to some government agencies has remained a major challenge. As of 2014, the country's electricity power supply was less than 5,000 Mega Watts (MW). Despite that the current government has made effort to increase the supply to 7,000MW (Fashola, 2018; National Bureau of Statistics, 2018), the distribution of the generated electric power has remained a major challenge for private companies in charge of the distribution.

A recent report from Power Africa (2018) revealed that only 45\% of Nigerians have access to electrical power. Out of which the urban areas have access to $55 \%$ while the rural areas have access to $36 \%$. This has affected the growth process of the country (Power Africa, 2018), as such, a large amount of clean electric power will be needed to achieve the goal of growing the Nigerian economy at the rate of 10-13\% to be part of the largest economies in the world by 2030 (Energy Commission of Nigeria (ECN), 2013).

Since 1999, there is a high expectation that the transition from military to democratic governance will bring rapid economic growth, largely because the democratic process provides citizens with the mandate to select the right leaders that will man the affairs of their country. But it appears that institutional limitations such as corruption and inadequate enforcement of rule of law have militated the impact of democratic governance on economic growth in Nigeria. Although addressing corruption is part of the agenda of the present government, reducing it to the barest minimum is required to feel the impact of democracy. As observed by Pushak et al. (2007), nations with high corruption ratings are less effective in enforcing rules and regulations.

This study empirically contributes to existing knowledge by employing a recent data to examine the nexus among electricity power, democratic governance and economic growth in the presence of control of corruption as an important institutional quality variable. To achieve this, dynamic regression is supported by fully modified regression, canonical regression and ordinary least squares regression as robustness check. This will enhance the reliability of the findings and the policy implications that will be derived from the findings of the study.

This study aims to examine the impact of democracy and economic growth on electricity generation in Nigeria. The study differs from other existing studies (Kirubi et al., 2009; NankaBruce, 2010; Ahlborg et al., 2015; Maji, 2015; Olatomiwa et al., 2015) by using voice and accountability to measure democracy and also including control of corruption as an additional institutional variable. Including control of corruption will assist policymakers in understanding the extent to which public goods such as electricity can be efficiently provided in a democratic movement. Besides using renewable electricity output as measure electricity, the study also uses high-bride regression methods to arrive at its conclusions. 
Other section of the study is organised as follows. Section 2 deals with literature review, section 3 discussed the methodology which comprises the model, estimation techniques, data sources and measurements. Section 4 focuses on discussing the results while section 5 concludes and provide some policy direction.

\section{Literature review}

Recent empirical works have examined the relationship between electricity energy, institutional quality, economic growth and other related variables. However, the link between electricity power, democratic governance and economic growth in Africa especially in the case of Nigeria seems to have eluded the literature. For instance, Chakamera and Alagidede (2018) studied the economic growth effects of both electricity stock and quality in Sub-Saharan Africa employing Ordinary Least Squares (OLS). The result revealed that Sub-Saharan Africa is mainly coal energy driven with a low proportion of renewable energy use. Coal was identified as the major cause of electricity-related pollution. Nevertheless, the region has great potentials for abundant renewable resources that can be harnessed.

Equally, Ahlborg et al. (2015) evaluate the degree to which household electricity consumption per head in Africa can be related to the countries' democratic governance and their institutional quality. Using a panel regression analysis, the findings show that institutional quality and democratic governance have an important impact on per capita household electricity consumption. To effectively provide general good like electricity, it was put forward that democratic governance where leaders are accountable to citizens is better than other forms of government (Acemoglu and Robinson, 2006). This was based on the fact that the electorates can replace any leader that did not provide the basic needs of life through the electoral process. Therefore, a direct and indirect link exist between public good such as electricity, democratic governance and economic growth (Heshmati and Kim, 2017). Efficient democratic governance provides electricity to the economic sector which the drives economic growth.

Furthermore, Aliyu et al. (2018) examine the prospects of renewable energy in South Africa, Egypt, and Nigeria using data from 1990 - 2011. The findings revealed several obstacles militating against the development of renewable energy in Africa to include the following: (i) ineffective policies and lack of implementing existing policies; (ii) insufficient funding of clean electricity-related government agencies; (iii) absence of advanced renewable energy technologies; (iv) low research output in the field of renewable and clean electricity. The study recommends the calibration of the existing institution and regulatory organs of renewable energy.

Again, Cabrera et al. (2018) assessed smart renewable energy penetration strategies in Spain Islands using a sample of $1970-2007$ period. The outcomes indicate that more than $75 \%$ renewable energy system could be achieved with the application of the region present technologies and close to $100 \%$ renewable energy system can be feasible when the present acquired technologies are optimized. Barasa et al. (2017) investigated how firm-level resources interact with regional institutional quality to explain innovation in Kenya, Tanzania, and Uganda. The findings suggest that the impact of firm-level resources which include clean energy varies depending on the institutional environment. Regional institutional quality importantly moderates 
the impacts of the firm-level resources. Similarly, Zalle (2019) focused on the link among natural resources (like clean electricity energy), human capital, quality of institutions and economic growth. Using a panel of 29 countries, the study found that the effectiveness of natural resources like energy depends on the qualities of human capital and institutions.

In addition, Balsalobre-Lorente et al. (2018) revealed that renewable electricity consumption and energy innovation improve environmental quality. More so, trade openness and the interaction between economic growth and renewable electricity consumption exert a positive impact on the environment. The finding suggests the need for renewable energy regulations to further promote energy innovation. Related studies (Bilgili et al., 20201; Zeraibi et al., 2021; Adedoyin et al., 2020; Balsalobre-Lorente and Leitão, 2020; Balsalobre-Lorente et al., 2019;) have investigated electricity energy and economic growth along other important variable like energy innovation, transport, ICT, financial development, environment and tourism. Despite these, we have not come across a recent study that examines electricity power, democratic governance and economic growth in Nigeria. This study uses recent data to contribute to knowledge in this respect.

\section{Research Method}

\subsection{Model and estimation strategy}

Theoretical postulations have suggested a direct and indirect link between democracy and public goods such as electricity, education, health care and economic growth (Ahlborg et al., 2015; Heshmati and Kim, 2017). One strand of the scholars maintained that since public good provision like electricity is part of the evaluation process of a democratic ruler, it was argued that democracy can facilitate the provision of public services (Deacon, 2003). Contrariwise, another school of taught argued that public goods like electricity require long time investment but elected leaders only have short regimes, as such, democratic institutions may not guarantee the provision of efficient public goods (Keefer,2006). Following the argument of Deacon (2003), the study hypothesized that good democratic governance can improve the provision of electricity which will then bring about economic growth. Therefore, the provision of electricity can be modelled as a function of democratic governance.

To model this relationship, the study rests on the Dynamic Ordinary Least Squares (DOLS) as its estimation strategy. The rationale of using the DOLS is that it can address endogeneity and simultaneity problems using the differenced leads and lags, as such, minimize the bias of the estimator (McCaskey and Kao, 1998; Kao and Chiang, 2000). The use of DOLS was further informed due to its efficiency and robustness in small sample estimation. To further, enhance the reliability of the results, we engaged the Fully Modified Ordinary Least Squares (FMOLS), the Canonical Cointegrating Regression (CCR) and the Ordinary Least Squares (OLS) for robustness check. The DOLS functional, econometric and dynamic models are respectively specified in equation (1-3) as follows.

$$
\begin{aligned}
& E L E C_{t}=f\left(D E M O C_{t}, \operatorname{CORRUP}_{t}, G D P G_{t}\right) \\
& \operatorname{lnELEC}_{t}=\gamma_{0}+\gamma_{1} \ln D E M O C_{t}+\gamma_{2} \operatorname{lnCORRUP_{t}}+\gamma_{3} \ln G D P G_{t}+\mu_{t}
\end{aligned}
$$


$\ln E L E C_{t}=\gamma_{0}+\gamma_{1} \ln D E M O C_{t}+\gamma_{2} \operatorname{lnCORRUP} P_{t}+\gamma_{3} \ln G D P G_{t}+\sum_{i=-j}^{n} \gamma_{i} \Delta \ln X_{t-i}+\mu_{t}(3)$

Where ELEC,DEMOC,CORRUP and GDPG represent electricity, democracy, control of corruption and Gross Domestic Product (GDP) growth. $\gamma_{0}$ is a drift parameter, $\mu_{t}$ is the stochastic error term expected to be normally distributed with zero mean and constant variance while $\sum_{i=-j}^{n} \gamma_{i} \Delta \ln X_{t-i}$ is vector of first difference of all the independent variables. We expect a positive relationship between the outcome variable electricity and two independent variables democracy and GDP growth. We expect an indirect relationship between the outcome variable electricity and independent variable corruption.

The expectations of the relationship between democratic governance and electricity may also depends on the quality of the data collected, measurement and the source of the data. Thus, the data for this study were sourced from World Development Indicators (WDI) and World Governance Indicators (WGI) covering the period of $1986-2020$. The variable of electricity is measured by renewable electricity output (\% of total electricity output) which is the share of electricity generated by renewable power plants in total electricity generated by all types of plants. Democracy is measured by voice and accountability which captures perceptions of the extent to which a country's citizens can participate in selecting their government, as well as freedom of expression, freedom of association, and freedom to express views in the media.

Corruption is proxy by control of corruption which captures perceptions of the extent to which public power is exercised for private gain, including both petty and grand forms of corruption. All the institutional quality variables are available from 1996. Economic growth is measured by GDP growth (annual \%). We anticipate that all the explanatory variables will have a positive impact on the electricity power supply.

\section{Results and discussions}

The result presentation commences with stationarity test and summary statistics of the variables in Table 1. The Augmented Dickey-Fuller (ADF) (Dickey and Fuller, 1981) and Phillips-Perron (PP) (Phillips and Perron, 1988) stationarity or unit root tests approach were used to ascertain the order of integration of the variables. Determining the order integration of series is important to avoid spurious regression results.

A variable is said to be stationary when it is time-invariant i.e. the mean and variance do not change over time. The stationarity test result shows that the variables are not stationary at the level form $\mathrm{I}(0)$, however, all the variables are stationary at first difference I(1) with the majority of the series significant at $1 \%$ level. This has further informed the use of DOLS as the estimation approach of this study as it can only be used when variables are stationary at first difference.

The result of the descriptive statistics is also presented on the right-hand side of Table 1 . The statistics reveal that the average value of electricity power is dominant in the observation, followed by the average value of democracy. On the other hand, electricity is the most volatile series as suggested by its standard deviation while GDP growth is the least volatile series in the descriptive statistics. The summary statistics also show that there is no case of missing value in observations. 
Table 1. Stationarity Test and Summary of Statistics

\begin{tabular}{|c|c|c|c|c|c|c|c|c|}
\hline & & \multicolumn{2}{|c|}{ ADF } & \multicolumn{2}{|c|}{$\mathrm{PP}$} & \multicolumn{3}{|c|}{ Summary statistics } \\
\hline & & Level & $1^{\text {st }}$ Diff. & Level & $1^{\text {st }}$ Diff. & Mean & $\begin{array}{l}\text { Std. } \\
\text { Dev. }\end{array}$ & Observation \\
\hline Electricity & & $\begin{array}{l}-1.469 \\
(0.806)\end{array}$ & $\begin{array}{l}-3.779 * * \\
(0.041)\end{array}$ & $\begin{array}{l}-0.663 \\
(0.062)\end{array}$ & $\begin{array}{l}-3.665^{*} \\
(0.051)\end{array}$ & 27.964 & 9.908 & 21 \\
\hline Democracy & & $\begin{array}{l}-2.343 \\
(0.169)\end{array}$ & $\begin{array}{l}- \\
7.618 * * * \\
(0.000)\end{array}$ & $\begin{array}{l}0.937 \\
(0.900)\end{array}$ & $\begin{array}{l}- \\
7.618^{* * *} \\
(0.000)\end{array}$ & 25.256 & 7.520 & 21 \\
\hline $\begin{array}{l}\text { Control } \\
\text { corruption }\end{array}$ & of & $\begin{array}{l}-2.074 \\
(0.528)\end{array}$ & $\begin{array}{l}- \\
4.783^{* * * *} \\
(0.00)\end{array}$ & $\begin{array}{l}-2.203 \\
(0.463)\end{array}$ & $\begin{array}{l}- \\
4.778^{* * * *} \\
(0.00)\end{array}$ & 10.501 & 4.1623 & 21 \\
\hline GDP growth & & $\begin{array}{l}-1.959 \\
(0.587)\end{array}$ & $\begin{array}{l}- \\
5.966 * * * \\
(0.006)\end{array}$ & $\begin{array}{l}-1.834 \\
(0.649)\end{array}$ & $\begin{array}{l}- \\
6.069 * * * \\
(0.000)\end{array}$ & 5.648 & 3.421 & 21 \\
\hline
\end{tabular}

Note: $* * * * *$ and $*$ indicate significance at $1 \%, 5 \%$ and $10 \%$ respectively. Values in parenthesis (.) are $p$-values. ADF stands for Augmented Dickey-Fuller test while PP stands for Phillips Perron test.

Having confirmed that the variables are stationary, a cointegration test was conducted using Johansen (1988) method and the result shows that there is a long-run relationship among the variables (see Table 2). Although the DOLS was used as the main estimation technique, to enhance the reliability of the results the FMOLS, CCR and OLS have further been used for robustness.

The long-run result shows that there is a negative and significant relationship between electric power and democracy in Nigeria. In order words democracy harms electricity, suggesting that democracy is taking place at the expense of electrical power generation in Nigeria. This is justified by the negative sign of coefficients of democracy in Table 2. The implication of this finding is that provision of public good like electricity which is one of the dividends of democracy have not been achieved.

Although democratic governance may not guarantee the provision of efficient public goods (Keefer, 2006) since public goods like electricity require long time investment whereas democratic leaders stay in office for a short period, it is expected that the 19 years of democratic regime experience in Nigeria should be able to provide efficient and affordable electricity to all citizens of the country. The policy recommendation of these findings is that policymakers should pay attention to the provision of public goods since democratic governance has not been able to provide basic electricity power to households, private sectors and even some government agencies in the country.

Furthermore, the empirical result in Table 2 for all the four estimators revealed that corruption also has a significant inverse relationship with electricity. This suggests that corruption harms 
electricity power supply in Nigeria. This result may not be surprising since the use of public power and office for private gains will not only hinder the provision of public goods like electricity but also economic growth at large.

There are claims in the media that a huge amount that was earmarked for electricity infrastructure during the first democratic dispensation was used for personal gains. Despite that, the fight against corruption is one of the main agenda of the present government, the implication of this finding for policy purpose is that the institutions in charge of enforcing the rule of law for effective democratic governance in Nigeria are weak. Thus, policymakers should further strengthen the institutions in charge of curbing corruption in Nigeria.

Nonetheless, the result provides evidence of a positive and significant relationship between electricity and economic growth. This result is theoretically intuitive as there is a positive causal link between public utilities like electric power and economic growth. For instance, improve and affordable electricity can enhance economic growth process just as a sustained economic growth process will provide bases for efficient and affordable electricity. We have also conducted a diagnostic test for serial correlation and normality test and present in the lower part of Table 2. The result shows that all the models have passed the tests.

Table 2. Impact of Democracy, Corruption and GDP Growth on Electricity

\begin{tabular}{|c|c|c|c|c|}
\hline & \multicolumn{4}{|c|}{ Dependent variable: electricity } \\
\hline & DOLS & FMOLS & CCR & OLS \\
\hline \multirow[t]{2}{*}{ Democracy } & $-1.526 * * *$ & $-1.012 * * *$ & $-1.029 * * *$ & $-0.781 * * *$ \\
\hline & $(0.238)$ & $(0.256)$ & $(0.259)$ & $(0.265)$ \\
\hline \multirow[t]{2}{*}{ Control of corruption } & $-0.639 *$ & $-0.864 *$ & $-0.792 *$ & $-0.719 *$ \\
\hline & $(0.334)$ & $(0.416)$ & $(0.415)$ & $(0.390)$ \\
\hline \multirow[t]{2}{*}{ GDP growth } & $2.130 * *$ & $1.066^{*}$ & $1.343^{*}$ & $0.973 *$ \\
\hline & $(0.728)$ & $(0.512)$ & $(0.659)$ & $(0.556)$ \\
\hline \multirow[t]{2}{*}{ Constant } & $59.441 * * *$ & $56.638 * * *$ & $54.316^{* * *}$ & $49.762 * * *$ \\
\hline & $(0.004)$ & $(8.861)$ & $(7.509)$ & $(7.171)$ \\
\hline $\mathrm{R}^{2}$ & 0.905 & 0.606 & 0.584 & 0.565 \\
\hline \multirow[t]{2}{*}{ Johansen Cointegration test } & Trace: $\mathbf{r}=0$ & Trace: $\mathbf{r} \leq 1$ & Max: $\mathbf{r}=0$ & Max. $\mathbf{r} \leq 1$ \\
\hline & $0.8847 * * *$ & $0.885 * * *$ & $0.988 * * *$ & $0.885^{* * *}$ \\
\hline \multirow[t]{2}{*}{ Normality tests } & 2.942 & 0.469 & 0.630 & 0.454 \\
\hline & [0.229] & {$[0.791]$} & {$[0.729]$} & {$[0.797]$} \\
\hline \multirow[t]{2}{*}{ Serial correlation tests } & 0.993 & 2.141 & 1.363 & 1.976 \\
\hline & {$[0.609]$} & {$[0.343]$} & {$[0.506]$} & {$[0.158]$} \\
\hline
\end{tabular}

Note: $* * *, * *$ and $*$ indicate significance at $1 \%, 5 \%$ and $10 \%$ respectively. Values in parenthesis (.) and [.] are standard errors and probability values respectively. DOLS stands for Dynamic Ordinary Least Squares (OLS); FMOLS stands for fully modified (OLS); CCR denotes Canonical Cointegrating regression OLS denotes Ordinary Least Squares. $\mathbf{r}$ is the null hypothesis for the Johansen cointegration test.

\section{Conclusion}

This study investigates the impact of democratic governance, corruption and economic growth on electricity power supply in Nigeria. High-bride regression methods were used to estimate data 
covering the 1986 - 2020 period. The result revealed a negative and significant impact of democracy and corruption on electricity power in Nigeria. On the other hand, the proxy for economic growth has shown a positive and important impact on electricity generation. This suggests that higher GDP growth will increase the supply of electricity in Nigeria. The empirical result has challenged our earlier hypothesis in the methodology section, that democratic governance will improve electricity power. However, the finding on the relationship between control of corruption, economic growth and electricity power are theoretically intuitive.

The two main implications of the study are as follows. Since democracy has provided evidence of a negative impact of electricity supply, the implication of this finding is that one of the dividends of democracy which is providing public good to the citizens have not been reap, as such, policymakers need to give more attention to the provision electricity supply as providing basic electrical power to households, private sectors and some government agencies will enhance the overall performance of the economy. Because electricity supply is important to households, businesses and even the government, promoting its supply by policymaker will further enhance inclusive growth and development.

Moreover, corruption has also revealed evidence of a negative and significant impact on electricity power generation in Nigeria. The implication of this result for policy purposes is that the institutions in charge of fighting corruption such as the Economic and Financial Crime Commissions (EFCC), the Independent Corrupt Practices Commission (ICPC) among others need to be further strengthened in Nigeria. Therefore, the effort of the present government in fighting corruption needs to be increased to reduce the global rating of Nigeria with regard to corrupt practices. Nations with a high rating of corruption are said to be less effective in enforcing rules and regulations. Thus, enlightenment of citizens on the importance of enforcing rules and regulations cannot be over emphasized.

The limitations of the study are (i) the study only used one measurement of institutional quality variables; (ii) the study only consider renewable electricity output (\% of total electricity output) to measure electricity power; (iii) economic growth was captured by gross domestic product growth. Future studies should consider additional index of institutional quality measurement, other renewable sources of generating electricity and per capital gross domestic product. Panel studies in this respect should also be considered in future studies.

\section{References}

Adedoyin, F.F., Bekun, F.V., Driha, O.M. Balsalobre-Lorente, D. (2020) The effects of air transportation, energy, ICT and FDI on economic growth in the industry 4.0 era: Evidence from the United States. Technological Forecasting and Social Change 160, 120297

Ahlborg, H., Boräng, F., Jagers, S. C. and Söderholm, P. (2015). Provision of electricity to African households: The importance of democracy and institutional quality. Energy Policy, 87, 125135.

Aliyu, A. K., Modu, B. and Tan, C. W. (2018). A review of renewable energy development in Africa: A focus in South. Renewable and Sustainable Energy Reviews, 81(June 2017), 2502-2518. 
Balsalobre-Lorente, D. Álvarez-Herranz, A., Shahbaz, M. (2019). The long-term effect of economic growth, energy innovation, energy use on environmental quality. Energy and Environmental Strategies in the Era of Globalization, 1-34

Balsalobre-Lorente, D., Leitão, N.C. (2020) The role of tourism, trade, renewable energy use and carbon dioxide emissions on economic growth: evidence of tourism-led growth hypothesis in EU-28. Environmental Science and Pollution Research 27 (36), 4588345896

Balsalobre-lorente, D., Shahbaz, M., Roubaud, D. and Farhani, S. (2018). How economic growth , renewable electricity and natural resources contribute to $\mathrm{CO} 2$ emissions? Energy Policy, 113(November 2017), 356-367.

Barasa, L., Knoben, J., Vermeulen, P., Kimuyu, P. and Kinyanjui, B. (2017). Institutions, resources and innovation in East Africa: A firm level approach. Research Policy, 46(1), 280-291.

Bilgili, F., Lorente, D.B., Kuşkaya, S., Ünlü, F., Gençoğlu, P., Rosha, P. (2021). The role of hydropower energy in the level of $\mathrm{CO} 2$ emissions: An application of continuous wavelet transform. Renewable Energy, 178, 283-294.

Canaria, G., Cabrera, P and Lund, H. (2018). Smart renewable energy penetration strategies on islands: The case of Gran Canaria. Energy 162 (2018) 421-443.

Chakamera, C. and Alagidede, P. (2018). Electricity crisis and the eff ect of CO2 emissions on infrastructure-growth nexus in Sub Saharan Africa. Renewable and Sustainable Energy Reviews, 94(July), 945-958.

Deacon, R. (2003). Dictatorship, democracy and the provision of public goods. Economics Working Paper. University of California at Santa Barbara, pp.11-99.

Dickey, A.D. and Wayne, Fuller, A. (1981). Likelihood ratio statistics for autoregressive time series with a unit root. Econometrica, 49, 1057-1072.

ECN. (2013). National energy policy. Federal Republic of Nigeria [Draft Revised Edition]. Available at www.energy.gov.ng/.

Fashola, B. (2018). Federal Ministry of Power, Works and Housing. Available at www.power.gov.ng/

Heshmati, A. and Kim, N. (2017). The relationship between economic growth and democracy: Alternative representation of technological change. Discussion Paper Series. IZA Institute of Labor and Economics.

Johansen, S. (1988). Statistical analysis of cointegration vectors. Journal of Economic Dynamics and Control 12, 231-254.

Kao, C. and Chiang, M. H. (2000). On the estimation and inference of a cointegrated regression in panel data. Advance Economy, 15, 179-222.

Keefer, P. (2006). Clientelism, credibility and the policy choices of young democracies. American Journal of Political Science, 51(October), 804-821. 
Kirubi, C., Jacobson, A., Kammen, D. M. and Mills, A. (2009). Community-based electric micro-grids can contribute to rural development: Evidence from Kenya. World Development, 37(7), 12081221.

Maji, I. K. (2015). Does clean energy contribute to economic growth? Evidence from Nigeria. Energy Reports 1 (2015), 145-150.

McCoskey, S., and Kao, C. (1998). A residual-based test of the null of cointegration in panel data. Economic Review, 17, 57-84.

Nanka-Bruce, O. (2010). The socio-economic drivers of rural electrification in Sub-Saharan Africa. Surrey Energy Economics Discussion Paper Series128.Surrey Energy Economics Centre, University of Surrey, $U K$.

NBS. (2018). National Bureau of Statistics. Available at https:www.nigerianstat.gov.ng

Olatomiwa, L., Mekhilef, S., Huda, A. S. N. and Ohunakin, O. S. (2015). Economic evaluation of hybrid energy systems for rural electrification in six geopolitical zones of Nigeria. Renewable Energy 83 (2015), 435-446.

Phillips, P. C. B. and Perron, P. (1988). Testing for a unit root in time series regression. Biometrika, 75(2), 335-346.

Power Africa. (2018). Nigeria power Africa fact sheet: Energy sector overview. Available at www.usaid.gov.power/

Pushak, T., Tiongson, E. R. and Varoudakis, A. (2007). Public finance, governance and growth in transition economies: Empirical evidence from 1992-2004. World Bank Policy Research Working Paper, No. 4255, Washington, D.C.

REMP. (2012). Renewable Energy Master Plan, Revised Edition. Available at www.energy.gov.ng/.

SDG. (2017).The Sustainable Development Goals Report. Available at www.millennium-institute.org

WDI. (2018). World Bank's World Development Indicators: Available at http://www. worldbank.org

WGI. (2018). World Bank's World Governance Indicators: Available at http://www. worldbank.org

Zallé, O. (2018). Natural resources and economic growth in Africa: The role of institutional quality and human capital. Resources Policy, (July), 1-9.

Zeraibi, A., Balsalobre-Lorente, D. Murshed, M. (2021). The influences of renewable electricity generation, technological innovation, financial development, and economic growth on ecological footprints in ASEAN-5 countries. Environmental Science and Pollution Research, 1-19

Copyrights

Copyright for this article is retained by the author(s), with first publication rights granted to the journal.

This is an open-access article distributed under the terms and conditions of the Creative Commons Attribution license (http://creativecommons.org/licenses/by/4.0/) 